Article

\title{
Structural and Physicochemical Properties of Tunisian Quercus suber L. Starches for Custard Formulation: A Comparative Study
}

\author{
Youkabed Zarroug ${ }^{1, *}$, Mouna Boulares ${ }^{2}$, Dorra Sfayhi ${ }^{1}$, Bechir Slimi ${ }^{3}$, Bouthaina Stiti ${ }^{4}$ (D), Kamel Zaieni ${ }^{3}$, \\ Sirine Nefissi ${ }^{2}$ and Mohamed Kharrat ${ }^{1}$
}

1 Field Crops Laboratory (LR20INRAT02), National Agricultural Research Institute of Tunisia (INRAT), University of Carthage, Ariana 2049, Tunisia; sfayhi.dorra@yahoo.fr (D.S.); mohamed_kharrat@outlook.com (M.K.)

2 Research Unit: Bio-Preservation and Valorization of Agricultural Products (UR13-AGR 02), Higher Institute of Food Industries (ESIAT), University of Carthage, Tunis 1003, Tunisia; boulares_mouna2006@yahoo.fr (M.B.); nefisi.sirine@gmail.com (S.N.)

3 Laboratoire des Nanomatériaux et Systèmes Pour les Énergies Renouvelables (LANSER), Centre de Recherches et des Technologies de l'Energie Technopole Borj Cedria, BT 95, Hammam Lif 2050, Tunisia; bechir.slimi0511@gmail.com (B.S.); kamelzayani.71@gmail.com (K.Z.)

4 National Institute of Research in Rural Engineering, Water and Forests BP 10, University of Carthage, Ariana 2080, Tunisia; stitibou@gmail.com

* Correspondence: zarrougyoukabed@yahoo.fr; Tel.: +216-93061341; Fax: +216-71231509

Citation: Zarroug, Y.; Boulares, M.; Sfayhi, D.; Slimi, B.; Stiti, B.; Zaieni,

K.; Nefissi, S.; Kharrat, M. Structural and Physicochemical Properties of Tunisian Quercus suber L. Starches for Custard Formulation: A Comparative Study. Polymers 2022, 14, 556

https://doi.org/10.3390/

polym14030556

Academic Editors: Antonio Zuorro André Ricardo Fajardo and Ismael Bellettini

Received: 14 November 2021

Accepted: 17 December 2021

Published: 29 January 2022

Publisher's Note: MDPI stays neutral with regard to jurisdictional claims in published maps and institutional affiliations.

Copyright: (C) 2022 by the authors. Licensee MDPI, Basel, Switzerland. This article is an open access article distributed under the terms and conditions of the Creative Commons Attribution (CC BY) license (https:// creativecommons.org/licenses/by/ $4.0 /)$

\begin{abstract}
The aim of the present study was to extract starch from acorn (Quercus suber L.) fruits using water and alkaline methods. Structural and functional properties of extracted starches were investigated and compared to those of corn and modified starches in order to determine their innovative potential application in food industry. The yield of extraction using the two methods was about $48.32 \%$ and $48.1 \%$. The isolated starches showed low moisture, fat and protein contents, revealing high purity and quality. Additionally, the starch extracted using the alkaline method (AAS) showed higher lightness (60.41) when compared to starch isolated using hot water (WAS). However, the lightest white color was found for studied commercial starches. Moreover, AAS starch exhibited the highest swelling power, solubility and water absorption, followed by WAS and commercial starches. Results showed that extracted acorn starches were characterized by greater enthalpy and gelatinization temperatures. Similar observations were noted using FT-IR spectra analysis for all analyzed starches. In addition, granule starches observed using scanning electron microscopy were found to be spherical and ovoid. However, from the analysis by X-ray diffraction, a crystalline pattern of C-type was found for acorn starches, while commercial starches presented an A-type pattern. As an innovative food application, these underexploited acorn starches were valued and served to produce new custards with improved functional properties and better microstructure when compared to commercial custard.
\end{abstract}

Keywords: acorn; starch; structure; technological properties; custard; characterization

\section{Introduction}

The genus Quercus, which belongs to the Fagaceae family, contains around 600 species worldwide [1] such as Quercus suber, Quercus robur, Quercus petraea, Quercus ilex, and Quercus pubescens [2]. The acorn fruit is widespread in the Mediterranean forests in North Africa, especially in Algeria, Morocco, and Tunisia. Traditionally, several acorn plants have been widely used in Mediterranean medicine and foods. Due to their high concentration of tannic acid, a mild toxin giving them a bitter taste, the acorn fruits are soaked in water, boiled, or roasted and then consumed in the form of flour or grilled as a substitute for coffee beans. In Tunisia, Quercus suber trees occupy almost 70,000 ha and predominantly 
grow in "Ain Drahem" and Tabarka [3]. Recent studies showed that acorn fruits contain several bioactive compounds such as polyphenols, sterols, and long-chain alcohols $[4,5]$ with interesting antioxidant activity [2]. In addition, Quercus fruits contain many valuable compounds such as fibers, proteins, minerals, and oil, as well as starch, constituting over $58 \%$ of the kernel [6]. Starch is the main reserve nutrient in plants, providing 70 to $80 \%$ of the world's human caloric consumption [5-7]. It is a biodegradable and renewable polysaccharide, which consists of two glucopyranose homopolymers: amylose and amylopectin [8]. Chemically, amylose has a linear structure consisting of D-glucopyranosyl subunits attached by $\alpha-(1 \rightarrow 4)$ glycoside linkages with the presence of slightly branched molecules. However, amylopectin is a broad branched polymer composed of $\alpha-(1 \rightarrow 4)$ -D-glucopyranose units linked by $\alpha-(1 \rightarrow 6)$ bonds at the branching points $[9,10]$. The most widely used starches have been extracted from many vegetable sources, especially from cereals, legumes, roots, and tuber crops [10]. To enhance the consumption of natural resources, many other new sources of starch are being studied, such as biri, ginger, arrowroot, sweet potato and yam [11], and maca or Peruvian carrot [12]. These native starches of different botanical origins reveal enormous diversity in their structure and composition, including their amylase, amylopectin, and minor constituent (lipid, protein, and mineral) contents. Starch is rarely consumed in its intact form and frequently used by industry in its native form. Most native starches are limited in their direct application because they are unstable with respect to changes in temperature, $\mathrm{pH}$, and shear forces. Therefore, native starches are often modified to enhance their technological and functional properties under the high heating temperatures used in industrial processes. In order to replace the chemically modified starches, particularly in the food industry, researchers and nutritionists are searching for new natural starch sources such as acorn fruits [6-13]. Recently, a few studies have reported that acorn starch has received some research interest in the food (e.g., cereals, snacks, dairy, soups, jelly) and nonfood industries [14], especially in the development of biomaterials (biofilms) [15]. In the food industry, starch is used particularly to improve the properties of baking flour and bakery products such as cakes and breads due to their high consumption. During their formulations, starch is one of the components responsible for broad technological functionality. Generally, starch is used as a food additive, hydrocolloid, thickener, emulsifier, and coating agent [16] in many industrial foods to improve their functional and sensory characteristics. For the acorn extraction starch, many chemical-based technologies have been extensively applied in research, such as alcohols-based extraction, alkaline-based extraction and acetone-based extraction [17-19]. However, Zhang et al. [20] studied the effect of both physical and chemical methods, including hot-water soaking, alkaline washing, ultrasonic-assisted ethanol soaking, and ultrasonic-assisted hot-water soaking, on the extracted acorn starch yield. Compared to other extracted starches from cassava, barley, potato, and wheat, little research has been devoted to the evaluation of the structural and functional characteristics of acorn starch [21]. Acorns are non-conventional and good sources of a new form of starch that was not valued until now in food industry. In fact, few studies have focused on the functional properties of acorn starch from Quercus species without any food applications. The first application of acorn starch was studied in the investigation by Zarroug et al. [13], who incorporated acorn starch during the production of a fermented dairy product to enhance its functional properties. To our knowledge, the use of acorn starch for custard formulation has not been reported before, which shows the importance of this innovative application aiming to add value to this underexploited raw material in the food industry. The objective of this study was, first, to extract native acorn starches using two different methods (water and alkaline extraction) and compare their structural and physicochemical properties with those of commercial corn starch and modified starch. Second, the study aimed to investigate selected properties of a newly formulated acorn-based custard to provide information on the potential incorporation of acorn starch into various industrial food applications. 


\section{Materials and Methods}

\subsection{Materials}

Acorn fruits belonging to the species Quercus Suber L. were manually collected from Beni $\mathrm{M}^{\prime}$ tir region of Jendouba in the northwestern Tunisia. Acorn kernels were hand-peeled, dried at $40^{\circ} \mathrm{C}$ for 3 days, and then milled into flour. The acorn flour was used to extract starch by two extraction methods: water extraction, as reported in the study by Singh and Singh [22], and alkaline extraction as described in the previous study by Zarroug et al. [13]. The starches extracted with the water and alkaline methods were named water acorn starch (WAS) and alkaline acorn starch (AAS), respectively. The obtained starches were dried at $40{ }^{\circ} \mathrm{C}$ for $12 \mathrm{~h}$ and milled into a fine powder. Then, they were stored in sealed bags at room temperature until analysis. Commercial corn (Zea mays L.) starch (CS) and chemically modified starch (MS) were purchased from the local market and were used to compare their functional properties with those of the two extracted acorn starches. All chemicals and reagents were of analytical grade.

\subsection{Starch Analysis}

\subsubsection{Chemical Composition}

Chemical composition of the extracted acorn starches was determined according to the AOAC methods for moisture, ash, protein, lipid, and carbohydrate contents [23]. The $\mathrm{pH}$ of acorn starch was determined using the method described by Achri et al. [24]. Color measurement of the studied samples was performed with a chromameter (Konika Minolta, CR-300, Tokyo, Japan) using the CIE LAB system $\left(\mathrm{L}^{*}, \mathrm{a}^{*}, \mathrm{~b}^{*}\right)$. The turbidity of starch suspensions was determined as described by Lan et al. [25] using a UV-visible spectrophotometer. A starch solution $(1 \%, w / v)$ was prepared and then heated for $30 \mathrm{~min}$ in a boiling water bath with continuous stirring until starch gelatinization. After that, the starch was cooled for $30 \mathrm{~min}$ at room temperature. The light transmittance, expressed by the turbidity, of the gelatinized starches was measured by spectrophotometer at $620 \mathrm{~nm}$, and distilled water was used as a blank [21].

\subsubsection{Solubility, Swelling Power, Water Absorption Capacity, Refrigeration, and} Freezing Stability

Solubility, water absorption, and swelling power of different starch samples at 60, 70, 80 , and $90^{\circ} \mathrm{C}$ were determined according to the method described in the previous study by Zarroug et al. [13]. The evaluation of starch stability under refrigeration and freezing was examined also according to Zarroug et al. [13]. Briefly, starch solution (6\% in water) was heated to $95^{\circ} \mathrm{C}$ and then cooled to $50{ }^{\circ} \mathrm{C}$ by maintaining each treatment for $15 \mathrm{~min}$. The syneresis rate was calculated after centrifugation of the solution at $4000 \mathrm{rpm}$ for $10 \mathrm{~min}$.

\subsubsection{Fourier Transform Infrared Spectroscopy}

All spectra were collected using a PerkinElmer Spectrum single bounce ATR accessory with a diamond crystal. Dry starches were equilibrated at laboratory humidity (50\% RH) and were dispersed in a matrix of $\mathrm{KBr}$ at room temperature. The obtained mixture was then pressed into pellets. The range of spectra was from 400 to $4000 \mathrm{~cm}^{-1}$ with a spectral resolution of $4 \mathrm{~cm}^{-1}$ [20].

\subsubsection{X-ray Diffraction (XRD)}

X-ray diffraction (Bruker D8 Advance) in the Bragg-Bentano configuration with Nifiltered $\mathrm{Cu} \mathrm{K} \alpha$ radiation $(\mathrm{k}=1.5418 \AA$ ) operated at $40 \mathrm{kV}$ and $40 \mathrm{~mA}$ was used to determine the degree of starch crystallinity according to the method reported by Zhang et al. [20]. Diffractograms were obtained in $2 \mathrm{~h}$ with a scanning speed of $2^{\circ} / \mathrm{min}$ and a scanning step of $0.02^{\circ}$. 


\subsubsection{Thermogravimetric (TGA) Analysis}

TGA is a technique where a mass loss of a sample can be measured as a function of time or temperature. Starch samples were analyzed by a thermogravimetric analyzer type Shimadzu TGA-50 (Shimadzu, Kyoto, Japan). Starch samples were heated from 20 to $500{ }^{\circ} \mathrm{C}$ in open alumina crucibles. A quantity of $8.0 \mathrm{mg}$ of sample was used in a synthetic air stream of $100 \mathrm{~mL} / \mathrm{min}$ with a heating rate of $10^{\circ} \mathrm{C} / \mathrm{min}$ [10].

\subsubsection{Thermal Properties}

Thermal properties of starch samples were measured using a differential scanning calorimeter (DSC, Q2000, TA Co., New Castle, PA, USA). Starch sample (3 mg) was weighed into a DSC aluminum pan and distilled water $(9 \mu \mathrm{L})$ was added with a micro syringe. The sample pans were hermetically sealed, reweighed, and allowed to stay overnight at room temperature in order to attain an even distribution of water before DSC analysis. Subsequently, the samples were heated from 20 to $120^{\circ} \mathrm{C}$ at a rate of $10{ }^{\circ} \mathrm{C} / \mathrm{min}$, and an empty pan was used as a reference for all measurements. During the scans, the flow rate of dry nitrogen was kept at $50 \mathrm{~mL} / \mathrm{min}$. The gelatinization temperatures $\left(\mathrm{T}_{0}, \mathrm{~T}_{\mathrm{p}}\right.$, and $\left.\mathrm{T}_{\mathrm{c}}\right)$ and gelatinization $(\Delta \mathrm{H})$ were obtained from the DSC software [20].

\subsubsection{Scanning Electron Microscopy (SEM)}

Acorn starch samples were dispersed evenly with a rubber suction bulb, placed on stub with double-sided adhesive tape, and coated with gold in an argon atmosphere. The surface of starch granules was analyzed under a scanning electron microscope (JSM-6360LV, JEOL, Tokyo, Japan) at an accelerating voltage of $20 \mathrm{kV}$.

\subsection{Custard Preparation and Analysis}

Custard recipe was prepared according to the following formula: $40 \mathrm{~g}$ of starch samples (WAS and AAS), $40 \mathrm{~g}$ sugar, $0.16 \mathrm{~g}$ vanilla flavor, and $500 \mathrm{~mL}$ whole fat milk. A commercial custard sample was also prepared in the same manner and used as control. For each custard sample, the ingredients were weighed into a glass and mixed with whole fat milk under mechanical stirring for $10 \mathrm{~min}$ and later warmed up to reach $100{ }^{\circ} \mathrm{C}$. The mixture was kept at $100{ }^{\circ} \mathrm{C}$ for 4 min and subsequently cooled back until reaching room temperature. The prepared water acorn starch custard (WASC), alkaline acorn starch custard (AASC), and commercial custard (CC) were subjected to physicochemical (pH, moisture, protein, ash, fat, carbohydrate, and color parameter) analysis. In addition, the syneresis of custard samples was determined according to the method described by Ben Moussa et al. [26]. The microstructure of custard samples was also observed using scanning electron microscopy (SEM).

\subsection{Statistical Analysis}

All experiments were carried out in three replications, and the mean values \pm STD were used for comparisons. Variance analysis (ANOVA) was performed using STATISTICA software to estimate significant differences between samples. Duncan's multiple range tests was used for comparison at the significance level of $5 \%(p<0.05)$.

\section{Results and Discussion}

\subsection{Acorn Starch Characterization}

\subsubsection{Physicochemical Characterization of Starches}

In order to evaluate the quality of the extracted acorn starches using water (WAS) and alkaline (AAS) methods, their physicochemical properties were determined and compared to those of corn starch (CS) and modified starch (MS). Results of the physicochemical characterization of WAS, AAS, CS, and MS starch samples are shown in Table 1. 
Table 1. Chemical composition of different starches.

\begin{tabular}{ccccc}
\hline Components & WAS & AAS & CS & MS \\
\hline Yield (\%) & $48.32 \pm 0.007^{\mathrm{a}}$ & $48.1 \pm 0.07^{\mathrm{b}}$ & - & - \\
\hline Moisture (\%) & $12.20 \pm 0.16^{\mathrm{b}}$ & $12.41 \pm 0.13^{\mathrm{b}}$ & $9.16 \pm 0.45^{\mathrm{c}}$ & $7.95 \pm 0.22^{\mathrm{a}}$ \\
\hline Fat (\%) & $0.44 \pm 0.007^{\mathrm{a}}$ & $0.61 \pm 0.028^{\mathrm{d}}$ & $0.35 \pm 0.014^{\mathrm{b}}$ & $0.47 \pm 0.01^{\mathrm{c}}$ \\
\hline Protein (\%) & $0.30 \pm 0.01^{\mathrm{d}}$ & $0.27 \pm 0.01^{\mathrm{c}}$ & $0.14 \pm 0.01^{\mathrm{b}}$ & $0.12 \pm 0.01^{\mathrm{a}}$ \\
\hline Ash (\%) & $0.35 \pm 0.02^{\mathrm{c}}$ & $0.24 \pm 0.04^{\mathrm{b}}$ & $0.17 \pm 0.005^{\mathrm{d}}$ & $0.09 \pm 0.02^{\mathrm{a}}$ \\
\hline Carbohydrates (\%) & $86.71 \pm 0.01^{\mathrm{a}}$ & $86.47 \pm 0.02^{\mathrm{b}}$ & $90.18 \pm 0.01^{\mathrm{c}}$ & $91.37 \pm 0.02^{\mathrm{d}}$ \\
\hline $\mathrm{pH}^{\mathrm{b}}$ & $5.66 \pm 0.05^{\mathrm{b}}$ & $5.85 \pm 0.01^{\mathrm{a}}$ & $6.61 \pm 0.02^{\mathrm{c}}$ & $6.81 \pm 0.01^{\mathrm{d}}$ \\
\hline $\mathrm{L}^{*}$ & $55.76 \pm 1.70^{\mathrm{a}}$ & $60.41 \pm 0.23^{\mathrm{a}}$ & $87.8 \pm 0.46^{\mathrm{c}}$ & $92.72 \pm 0.31^{\mathrm{b}}$ \\
\hline $\mathrm{a}^{*}$ & $1.47 \pm 0.234^{\mathrm{d}}$ & $0.89 \pm 0.02^{\mathrm{c}}$ & $-0.27 \pm 0.04^{\mathrm{b}}$ & $-1.98 \pm 0.12^{\mathrm{a}}$ \\
\hline $\mathrm{b}^{*}$ & $15.81 \pm 0.04^{\mathrm{a}}$ & $15.18 \pm 0.64^{\mathrm{a}}$ & $-1.15 \pm 0.13^{\mathrm{a}}$ & $3.36 \pm 0.22^{\mathrm{a}}$ \\
\hline Transmittance $(\%)^{\mathrm{a}}$ & $56.10 \pm 0.75^{\mathrm{c}}$ & $40.80 \pm 0.45^{\mathrm{a}}$ & $15.67 \pm 0.62^{\mathrm{d}}$ & $23.67 \pm 0.99^{\mathrm{b}}$ \\
\hline
\end{tabular}

Different letters in the same row indicate significantly different mean \pm standard deviation of triplicates $(p<0.05)$. WAS: water acorn starch, AAS: alkalis acorn starch, CS: corn starch, MS: modified starch.

The yield values observed for WAS and AAS were about $48.32 \%$ and $48.1 \%$, respectively. The starch yield from acorn Quercus Suber L. was higher than that reported in our previous study [13] on Quercus ilex L. starch (34.5\%). In the same context, Irinislimane et Belhaneche Bensemr [27] and Correia et al. [28] found starch yields of $21 \%$ and $31.4 \%$ in Quercus Suber L., respectively. Previous studies have shown some variations in starch yield for starches extracted from bambara samples (values varied from 22 to 33\%) [29] and cassava samples (values ranged from 67.36 to 81.13\%) [30]. Significant differences at $p \leq 0.05$ were observed in terms of ash, fat, carbohydrates, and protein values for the four studied starches, while no significant difference was found between WAS and AAS in terms of moisture content values. The moisture content values for WAS and AAS were $12.2 \%$ and $12.41 \%$, respectively, and these values were closely related to the standard range recommended by codex alimentarius $(<14 \%)$ for safe storage and minimal microbial growth leading to longer shelf life. Among all starches, the lowest moisture content was observed in the MS sample (7.95\%). According to Kormin et al. [31], a moisture content lower than $10 \%$ is specified for incorporation into a low-density polyethylene matrix for the production of biodegradable products. The values for protein content in the studied starches were in the range of $0.12-0.30 \%$, and the highest value was observed in the WAS sample. This result was lower than that found $(0.92 \%)$ in the work on Quercus ilex L. starch [13]. The fat content in the studied starches ranged between $0.44 \%$ and $0.61 \%$, and the highest fat content was noted in the AAS sample. These findings are in accordance with those obtained by Pérez et al. [21] and Shadrack et al. [30] on ramon $(0.49 \%)$ and cassava $(0.17 \%)$ starches, respectively. In general, the lipids and proteins in starch granules can increase their functionality. The protein in starch granules is associated with grain hardness, while the lipids can considerably reduce the swelling power of the starch paste. The ash contents in WAS and AAS was about $0.35 \%$ and $0.24 \%$, respectively. These values are higher than those of commercial CS (0.17\%) and MS (0.07\%) samples. According to Zarroug et al. [13], the low protein, fat, and ash contents indicate high extracted starch purity and quality. The $\mathrm{pH}$ values for the starch samples ranged between 5.66 (WAS) and 6.81 units (MS). The obtained values for the extracted acorn starches (WAS and AAS) were lower than those found by Elmi et al. [32] in potato starch (6.22 unit). The AAS sample showed higher $\mathrm{pH}$ values when compared to the WAS sample. This variation was explained by the application of the $\mathrm{NaOH}$ concentration at $0.25 \mathrm{M}$. According to Usman et al. [33], high pH could lead to undesirable protein modification as well as molecular cross linkage and rearrangements resulting in the formation of toxic compounds. A positive correlation was obtained between the $\mathrm{pH}$ value, the fat, and the protein content [34]. The color of starch samples has an 
impact on their quality and purity. It may also influence consumer preferences for the final prepared product. According to Franklin et al. [16], a high value for lightness ( $L^{*}$ value) and a low value for chroma $\left(a^{*}\right.$ and $\left.b^{*}\right)$ are desired in starches. The extracted acorn starches (WAS and AAS) showed no significant difference $(p \leq 0.05)$ in $\mathrm{L}^{*}$ and $\mathrm{b}^{*}$ values, while, a significant difference was found between the $\mathrm{a}^{*}$ values of these starches. Results revealed that commercial starches have higher $\mathrm{L}^{*}$ values compared to the extracted acorn starch samples. However, among these extracted starches, the AAS showed a higher $\mathrm{L}^{*}$ value (60.41) and lower $a^{*}(0.89)$ and $b^{*}(15.18)$ values when compared to the WAS sample. These findings were confirmed by the lower contents of protein and ash in AAS compared to WAS sample. In addition, the low $\mathrm{L}^{*}$ values observed in the extracted acorn starches could be attributed to the presence of phenolic compounds in acorn flour. These phenolic compounds cannot be removed without oxidative modification, which eliminates the pigmented compounds by reaction with the appropriate reagent. Authors suggested that the relatively high $\mathrm{L}^{*}$ values (greater than 90) and low $a^{*}$ and $b^{*}$ values of starches are indexes of purity [29]. In general, turbidity is used to characterize the retrogradation behavior of diluted starch paste [35]. The turbidity of the commercial starches (CS and MS) was lower than that of the acorn extracted starches (WAS and AAS) (Table 1). In addition, the WAS exhibited a higher turbidity value compared to AAS, because it contained higher protein and ash content. The high turbidity value was attributed to less complete swelling of starch granules, leading to the formation of a network between amylose and amylopectin chains that were leached out of the granules during gelatinization [36] and had a significant effect on the reflection or scattering of light.

\subsubsection{Swelling Power, Solubility, and Water Absorption of Starches}

Results for the swelling power, solubility, and water absorption of different starches at temperatures ranging from 60 to $90{ }^{\circ} \mathrm{C}$ are presented in Table 2. The swelling power, solubility, and water absorption increased significantly $(p<0.05)$ from 60 to $90{ }^{\circ} \mathrm{C}$ among the studied starches, and the AAS sample showed higher values compared to the WAS sample. The observed swelling power values in AAS (6.05-22.51 g/g) and WAS (3.01-20.7 g/g) were higher compared to those of starch extracted from Quercus fabri Hance (4.7-13.5 g/g) but lower than those of Quercus ilex starch (4-20.76 g/g) [13] and sweet potato starch (35-40 g/g) [37]. The high swelling power of the starch samples may be attributed to an increase in the amorphous portion content [38], the starch molecule's ability to hold water, and the degree of crystallinity [39]. The highest values for solubility and water absorption capacity, respectively, were found in the AAS sample at $90^{\circ} \mathrm{C}(13.3 \%$ and $14 \mathrm{~g} / \mathrm{g})$ followed by WAS $(7.27 \%$ and $13.97 \mathrm{~g} / \mathrm{g})$, CS $(6.15 \%$ and $8.31 \mathrm{~g} / \mathrm{g})$, and MS $(4.34 \%$ and $5.8 \mathrm{~g} / \mathrm{g})$. These solubility values were lower than those reported by Jiang et al. [40] for starches extracted from five different Dioscorea L. species, ranging from 11.14 to $30.04 \%$ at the temperature of $95^{\circ} \mathrm{C}$.

Table 2. Swelling power, solubility, and water absorption of different starches.

\begin{tabular}{|c|c|c|c|c|c|c|c|c|c|c|c|c|}
\hline \multirow[b]{2}{*}{ Samples } & \multicolumn{4}{|c|}{ Solubility (\%) } & \multicolumn{4}{|c|}{ Swelling Power (g Water/g Starch) } & \multicolumn{4}{|c|}{ Water Absorption (g Water/g Starch) } \\
\hline & $60^{\circ} \mathrm{C}$ & $70^{\circ} \mathrm{C}$ & $80^{\circ} \mathrm{C}$ & $90^{\circ} \mathrm{C}$ & $60^{\circ} \mathrm{C}$ & $70^{\circ} \mathrm{C}$ & $80^{\circ} \mathrm{C}$ & $90^{\circ} \mathrm{C}$ & $60^{\circ} \mathrm{C}$ & $70^{\circ} \mathrm{C}$ & $80^{\circ} \mathrm{C}$ & $90^{\circ} \mathrm{C}$ \\
\hline WAS & $\begin{array}{l}0.19 \pm \\
0.01^{\mathrm{a}}\end{array}$ & $\begin{array}{l}3.37 \pm \\
0.01^{\mathrm{c}}\end{array}$ & $\begin{array}{l}5.37 \pm \\
0.02^{c}\end{array}$ & $\begin{array}{c}7.27 \pm \\
0.01^{\mathrm{c}}\end{array}$ & $\begin{array}{l}3.01 \pm \\
0.01^{\mathrm{a}}\end{array}$ & $\begin{array}{l}8.51^{ \pm} \\
0.01^{\mathrm{c}}\end{array}$ & $\begin{array}{c}10.06 \pm \\
0.01^{\mathrm{c}}\end{array}$ & $\begin{array}{l}20.7 \pm \\
0.01^{c}\end{array}$ & $\begin{array}{l}3.18 \pm \\
0.01^{\mathrm{c}}\end{array}$ & $\begin{array}{l}7.36 \pm \\
0.01^{c}\end{array}$ & $\begin{array}{r}11.75 \pm \\
0.01^{\mathrm{d}}\end{array}$ & $\begin{array}{r}13.97^{ \pm} \\
0.01^{\mathrm{c}}\end{array}$ \\
\hline AAS & $\begin{array}{l}0.33^{ \pm} \\
0.01^{\mathrm{c}}\end{array}$ & $\begin{array}{l}4.44 \mathrm{t} \\
0.01^{\mathrm{d}}\end{array}$ & $\begin{array}{l}7.19 \pm \\
0.01^{\mathrm{d}}\end{array}$ & $\begin{array}{l}13.3 \pm \\
0.14^{\mathrm{d}}\end{array}$ & $\begin{array}{l}6.05 \pm \\
0.02 \mathrm{~d}\end{array}$ & $\begin{array}{l}11.3 \pm \\
0.14^{\mathrm{d}}\end{array}$ & $\begin{array}{c}14.03 \pm \\
0.01^{\mathrm{a}}\end{array}$ & $\begin{array}{l}22.51 \pm \\
0.01 \mathrm{~d}\end{array}$ & $\begin{array}{l}4.32 \pm \\
0.02 \mathrm{~d}\end{array}$ & $\begin{array}{l}8.44 \pm \\
0.01 \mathrm{~d}\end{array}$ & $\begin{array}{r}11.21^{ \pm} \\
0.01^{\mathrm{c}}\end{array}$ & $\begin{array}{c}14 \pm \\
0.01^{d}\end{array}$ \\
\hline MS & $\begin{array}{l}1.89 \pm \\
0.01 \mathrm{~d}\end{array}$ & $\begin{array}{c}0.14{ }^{ \pm} \\
0.01^{\mathrm{a}}\end{array}$ & $\begin{array}{c}0.47 \pm \\
0.01^{\mathrm{a}}\end{array}$ & $\begin{array}{l}4.34 \pm \\
0.21^{\mathrm{a}}\end{array}$ & $\begin{array}{l}4.83^{ \pm} \\
0.01^{c}\end{array}$ & $\begin{array}{c}3.17 \pm \\
0.01^{\mathrm{a}}\end{array}$ & $\begin{array}{l}3.36 \pm \\
0.01 \mathrm{~d}\end{array}$ & $\begin{array}{c}3.68 \pm \\
0.01^{\mathrm{a}}\end{array}$ & $\begin{array}{l}1.88 \pm \\
0.01^{\mathrm{a}}\end{array}$ & $\begin{array}{l}4.14 \pm \\
0.01^{\mathrm{a}}\end{array}$ & $\begin{array}{c}5.34{ }^{ \pm} \\
0.01^{\mathrm{a}}\end{array}$ & $\begin{array}{l}5.8 \pm \\
0.01^{\mathrm{a}}\end{array}$ \\
\hline CS & $\begin{array}{l}0.2 \pm \\
0.01^{\mathrm{b}}\end{array}$ & $\begin{array}{l}0.3 \pm \\
0.01^{\mathrm{b}}\end{array}$ & $\begin{array}{l}3.19 \pm \\
0.01^{b}\end{array}$ & $\begin{array}{l}6.15 \pm \\
0.00^{\mathrm{b}}\end{array}$ & $\begin{array}{l}3.82 \mathrm{t} \\
0.01^{\mathrm{b}}\end{array}$ & $\begin{array}{l}8.44 \pm \\
0.08^{\mathrm{b}}\end{array}$ & $\begin{array}{l}8.59 \pm \\
0.01^{b}\end{array}$ & $\begin{array}{c}11.29 \pm \\
0.01^{\mathrm{b}}\end{array}$ & $\begin{array}{c}2 \pm \\
0.01^{b}\end{array}$ & $\begin{array}{l}6.02 \pm \\
0.01^{b}\end{array}$ & $\begin{array}{l}6.28 \pm \\
0.02 \mathrm{~b}\end{array}$ & $\begin{array}{l}8.31 \pm \\
0.01^{b}\end{array}$ \\
\hline
\end{tabular}

Different letters in the same row indicate significantly different mean \pm standard deviation of triplicates $(p<0.05)$ WAS: water acorn starch, AAS: alkaline acorn starch, CS: corn starch, MS: modified starch. 
The water absorption capacity corresponds to the integrity of starch in aqueous solutions and the volume of the formed gel, and it depends also on the availability of hydrophilic groups and on the capacity of the macromolecule to form a gel. The obtained water absorption results were higher than those reported by previous research [16] on C. angustifolia starch. These variations are due to many differences in the bonding strengths within the starch granules between amorphous and crystalline domains, which are influenced by granule starch characterization and the dissimilarity in amylose and amylopectin structure, including molecular weight distribution, chain length, degree/length of branching, and amylose-amylopectin ratio [41]. The reason for the higher solubility and water absorption capacity could be attributed to the ability of starch to absorb and retain water in the AAS sample and also to its crystalline molecular structure [20]. In fact, during the starch extraction at a high temperature, this crystalline structure may be broken and changed, causing the formation of bonds between the water molecules and the free hydroxyl groups of amylose and amylopectin chains. Authors suggested also that the method used for starch extraction may have an effect on the starch properties and may result in starches with different levels of surface-associated material, which may impact starch water absorption and swelling [39]. Indeed, Zhang et al. [20] reported that acorn starch isolated using the ultrasonic-assisted ethanol soaking method had relatively higher values for swelling power $(24.99 \mathrm{~g} / 100 \mathrm{~g})$ and solubility $(15.22 \%)$ at $90{ }^{\circ} \mathrm{C}$ compared to that obtained with other methods.

\subsubsection{Refrigeration and Freezing Stability of Starches}

The stability variations in different studied starches under refrigeration and freezing conditions during storage times of $24,48,72,96$, and $120 \mathrm{~h}$ are shown in Table 3.

Table 3. Refrigeration and freezing stability of different starches.

\begin{tabular}{|c|c|c|c|c|c|c|c|c|}
\hline \multirow[b]{2}{*}{ Time (h) } & \multicolumn{4}{|c|}{ Syneresis to Refrigeration at $4{ }^{\circ} \mathrm{C}(\%)$} & \multicolumn{4}{|c|}{ Syneresis to Refrigeration at $-20^{\circ} \mathrm{C}(\%)$} \\
\hline & WAS & AAS & MS & CS & WAS & AAS & MS & CS \\
\hline 24 & $40.4 \pm 0.01^{\mathrm{b}}$ & $42.82 \pm 0.01^{\mathrm{c}}$ & $46.57 \pm 0.01^{\mathrm{d}}$ & $39.62 \pm 0.01^{\mathrm{a}}$ & $54.97 \pm 0.01^{\mathrm{c}}$ & $46.66 \pm 0.01^{b}$ & $35.44 \pm 0.01^{\mathrm{a}}$ & $56.04 \pm 0.01^{\mathrm{d}}$ \\
\hline 48 & $45.85 \pm 0.01^{\mathrm{c}}$ & $44.46 \pm 0.01^{\mathrm{b}}$ & $62.58 \pm 0.01^{\mathrm{d}}$ & $43.34 \pm 0.01^{\mathrm{a}}$ & $59.96 \pm 0.01^{\mathrm{d}}$ & $47.62 \pm 0.01^{\mathrm{c}}$ & $37.32 \pm 0.01^{\mathrm{a}}$ & $56.27 \pm 0.01^{b}$ \\
\hline 72 & $46.06 \pm 0.01^{\mathrm{c}}$ & $44.79 \pm 0.01^{\mathrm{b}}$ & $72.32 \pm 0.01^{\mathrm{d}}$ & $43.6 \pm 0.01^{\mathrm{a}}$ & $64.01 \pm 0.01^{\mathrm{a}}$ & $55.79 \pm 0.01^{\mathrm{c}}$ & $42.02 \pm 0.01^{\mathrm{b}}$ & $58.92 \pm 0.01^{\mathrm{d}}$ \\
\hline 96 & $46.93 \pm 0.01^{b}$ & $45.98 \pm 0.02^{\mathrm{a}}$ & $79.16 \pm 0.01^{\mathrm{d}}$ & $47.55 \pm 0.01^{\mathrm{c}}$ & $64.73 \pm 0.01^{\mathrm{d}}$ & $61.5 \pm 0.01^{\mathrm{b}}$ & $44.17 \pm 0.01^{\mathrm{a}}$ & $62.01 \pm 0.01^{c}$ \\
\hline 120 & $62.99 \pm 0.03^{b}$ & $46.07 \pm 0.01^{\mathrm{a}}$ & $92.6 \pm 0.01^{\mathrm{d}}$ & $73.03 \pm 0.01^{\mathrm{c}}$ & $69.77 \pm 0.01^{\mathrm{d}}$ & $63.04 \pm 0.01^{\mathrm{c}}$ & $61.4 \pm 0.01^{\mathrm{a}}$ & $62.36 \pm 0.01^{b}$ \\
\hline
\end{tabular}

Different letters in the same row indicate significantly different mean \pm standard deviation of triplicates $(p<0.05)$. WAS: water acorn starch, AAS: alkaline acorn starch, CS: corn starch, MS: modified starch.

Results showed that the syneresis values at $4{ }^{\circ} \mathrm{C}$ and $-20{ }^{\circ} \mathrm{C}$ of studied starches increased significantly $(p<0.05)$ with the increase in storage time. During 5 weeks of storage at $4{ }^{\circ} \mathrm{C}$, the syneresis of acorn starch gels ranged from $42.4 \%$ to $62.99 \%$ and $41.82 \%$ to $46.07 \%$ for WAS and AAS, respectively, and the highest values were observed in the WAS sample. The same tendency was observed during freezing storage $\left(-20^{\circ} \mathrm{C}\right)$ for syneresis of the extracted acorn starches. In the current study, the syneresis values at $-20{ }^{\circ} \mathrm{C}$ for the AAS sample were higher than those reported in a previous study [13] on Quercus ilex L. starch (34.5\%). Several studies reported that the high level of amylose content in starches could be the major reason for the high syneresis. Starches extracted from potato, maize, taro, and cassava present high syneresis, due to the large amount of water expelled during the retrograding process [21-30].

\subsubsection{Thermal and Retrogradation Properties}

A differential scanning calorimeter (DSC) was used to study the effect of thermal processing on the hydrated starch and to calculate the heat energy needed for starch gelatinization [42]. Thermal and retrogradation properties of different starches are summarized in Table 4 . The To, Tp, and Tc temperature values for the studied starches ranged from 
$39.32{ }^{\circ} \mathrm{C}$ (MS) to $45.18{ }^{\circ} \mathrm{C}$ (AAS), $73.72{ }^{\circ} \mathrm{C}$ (MS) to $84.66^{\circ} \mathrm{C}$ (AAS) and $115.35^{\circ} \mathrm{C}$ (MS) to $118.92^{\circ} \mathrm{C}$ (AAS), respectively. Results showed that the highest To, Tp, and Tc values were observed in AAS, followed by WAS, CS, and MS samples. We noted also that the extracted acorn starches (AAS and WAS) showed higher thermal temperatures and enthalpy values compared to other commercial starches (CS and MS).

Table 4. Thermal properties of different starches.

\begin{tabular}{cccccc}
\hline \multirow{2}{*}{ Samples } & \multicolumn{5}{c}{ Thermal Properties } \\
\cline { 2 - 6 } & $\mathbf{T}_{\mathbf{0}}\left({ }^{\circ} \mathbf{C}\right)$ & $\mathbf{T}_{\mathbf{P}}\left({ }^{\circ} \mathbf{C}\right)$ & $\mathbf{T}_{\mathbf{c}}\left({ }^{\circ} \mathbf{C}\right)$ & $\mathbf{G R}\left({ }^{\circ} \mathbf{C}\right)$ & $\Delta \mathbf{H}_{\mathbf{G}}(\mathbf{J} / \mathbf{g})$ \\
\hline AAS & $45.18 \pm 0.45^{\mathrm{a}}$ & $84.66 \pm 0.36^{\mathrm{c}}$ & $118.92 \pm 0.20^{\mathrm{a}}$ & $78.96 \pm 0.26^{\mathrm{a}}$ & $23.40 \pm 0.09^{\mathrm{a}}$ \\
\hline WAS & $41.67 \pm 0.25^{\mathrm{b}}$ & $78.36 \pm 0.83^{\mathrm{d}}$ & $117.41 \pm 0.80^{\mathrm{a}}$ & $75.38 \pm 0.86^{\mathrm{b}}$ & $17.67 \pm 0.04^{\mathrm{b}}$ \\
\hline CS & $40.53 \pm 0.60^{\mathrm{b}}$ & $76.75 \pm 0.40^{\mathrm{b}}$ & $116.83 \pm 0.7^{\mathrm{a}}$ & $70.44 \pm 0.91^{\mathrm{c}}$ & $18.19 \pm 0.27^{\mathrm{c}}$ \\
\hline MS & $39.32 \pm 0.74^{\mathrm{c}}$ & $73.72 \pm 0.57^{\mathrm{a}}$ & $115.35 \pm 0.20^{\mathrm{a}}$ & $68.80 \pm 0.44^{\mathrm{d}}$ & $19.79 \pm 0.94^{\mathrm{d}}$ \\
\hline
\end{tabular}

Different letters in the same row indicate significantly different mean \pm standard deviation of triplicates $(p<0.05)$ $\mathrm{T}_{0}$ : onset temperature, $\mathrm{T}_{\mathrm{P}}$ : peak temperature, $\mathrm{T}_{\mathrm{C}}$ : conclusion temperature, $\Delta \mathrm{H}_{\mathrm{G}}$ : enthalpy of gelatinization, GR: gelatinization range $2\left(\mathrm{Tp}-\mathrm{T}_{0}\right)$.

From an industrial point of view, the onset temperature $\left(T_{0}\right)$, which represents the initiation of the gelatinization stage in starch granules, is associated with the costs of the used processes in terms of energy and time, and thus a low temperature is required by manufacturers.

Previous study on acorn starches revealed gelatinization temperatures and enthalpy values ranging from 55 to $75.2^{\circ} \mathrm{C}$ and 6.52 to $20.8 \mathrm{~J} / \mathrm{g}$, respectively [10,43]. The greater gelatinization temperatures in acorn starches may be attributed to the longer double-helix chain of the crystal layer, which needs more energy to destroy the crystal structure compared to commercial starches. These findings are in accordance with previous studies on Quercus ilex, Quercus suber, and Quercus rotundifolia starches [10,39]. The thermal properties of the CS sample were similar to those found by Pérez-Pacheco et al. [21]. The gelatinization enthalpy $(\triangle \mathrm{HG})$ values for all studied starches ranged from 17.67 (WAS) to 23.40 (AAS) J/g. According to Boukhelkhal and Moulai-Mostefa, [10], the enthalpy of starch gelatinization is related to starch structure and molecular arrangement; usually, high enthalpy values are correlated to high organization of the amylopectin crystals. Furthermore, the amylose content could also influence the enthalpy of gelatinization since the studied starches were more organized and required higher energy to break hydrogen bonding. Therefore, the alkalis extracted acorn starch (AAS) retained a better molecular order than the WAS sample. In this study, the thermal properties differed from one type of starch to another, and these variations were due to several factors such as the difference in starch extraction methods, mineral composition, amylose/amylopectin ratio, starch granule morphology, starch structural arrangement, and botanical source, as well as the environmental conditions [10-44].

\subsubsection{X-ray Diffraction and FTIR Spectral Analysis}

The molecular arrangement of the extracted starch granules was determined by $\mathrm{X}$-ray diffraction and is shown in Figure 1a. The structural crystallinity of starch granules depends on their botanical source and is classified into three types of crystallinity patterns: A (Bragg angle $2 \theta$ at about $15.3^{\circ} ; 17.1^{\circ} ; 18.2^{\circ}$ and $23.5^{\circ}$ ), B (Bragg angle $2 \theta$ at about $14.4^{\circ} ; 17.2^{\circ}$; $22.2^{\circ}$ and $24.0^{\circ}$ ) and $C$ (Bragg angle $2 \theta$ at approximately $15.3^{\circ} ; 17.3^{\circ}$ and $23.5^{\circ}$ ) [30-45]. In general, most cereal starches are classified as type A. The arrowroot, cassava, and other plant tuber starches were reported to also have an A-type crystalline structure [45]. Native starches from various botanical sources are usually divided into A-, B- and C-type according to their crystallinity types. The studied CS and MS starches were X-ray A pattern crystals, with diffraction peaks corresponding to the emission angles $(2 \theta)$ of $15.3^{\circ}, 17.4^{\circ}, 18^{\circ}, 20^{\circ}$, and $23^{\circ}$. Similar findings were obtained by Ascheri [46] and Teixeira et al. [47] on Adlay (Coix lacryma Jobi L.) and waxy maize starches, respectively. However, the extracted acorn starches (WAS and AAS) showed strong reflections at $15.3^{\circ}$ and $23^{\circ}$ of $2 \theta$. Results revealed 
that acorn starches are classified as type A. In addition, minor peaks were observed at $17.4^{\circ}$ and $19.4^{\circ}$ of $2 \theta$, which are attributed to starches of type B. These results showed that acorn starches represent a mixture of type A and B crystallinity patterns. Similar results were reported by Zarroug et al. [13] for starch extracted from Quercus ilex L. The C-type crystalline structure consists of A- and B-type crystallites, so the X-ray diffraction pattern can contain various superpositions of the characteristic diffraction peaks depending on the ratio between the contents of these polymorphs [48]. Numerous other studies have already been conducted on the X-ray diffraction of acorn starches and showed a C-type [20-43]. The differences in the diffraction pattern of starch granules are mainly influenced by the genotypic, agronomic, and growing conditions of the source plant [49].

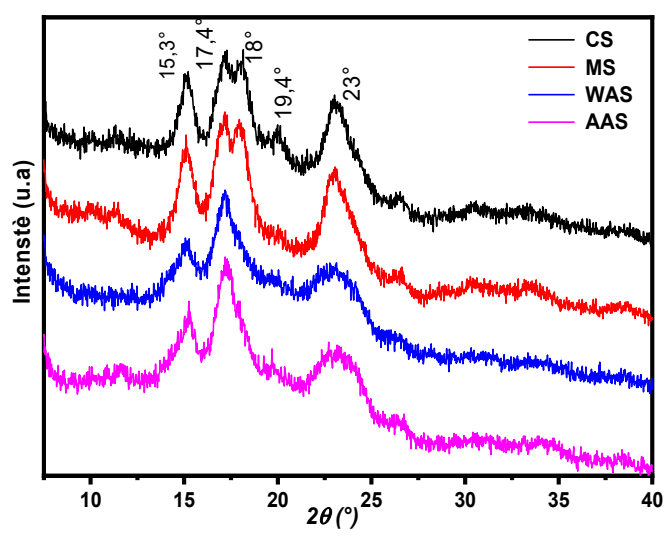

(a)

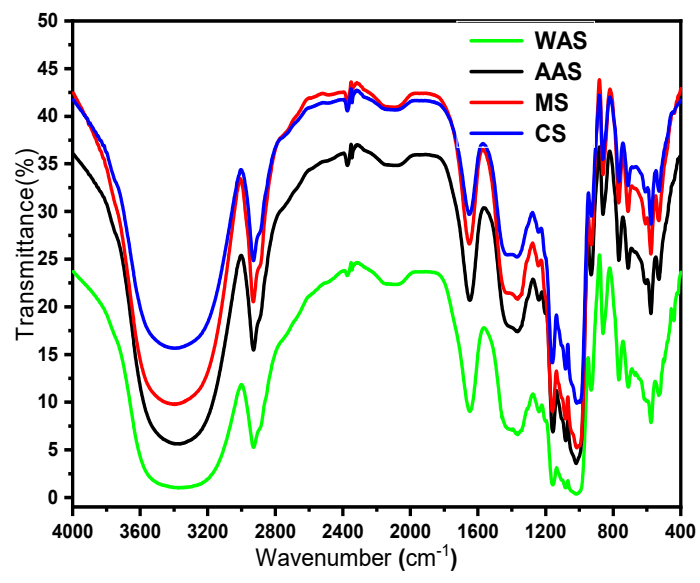

(b)

Figure 1. X-ray diffraction pattern (a) and FT-IR spectra (b) of different starches. WAS: water acorn starch, AAS: alkaline acorn starch, CS: corn starch, MS: modified starch.

The FT-IR spectra of the starch samples are shown in Figure 1b. The observed spectra are similar for the four studied starches, with a broad intense band of $3600-3000 \mathrm{~cm}^{-1}$ representing the stretching vibrations of $\mathrm{O}-\mathrm{H}$ bonds in the hydroxyl groups. A peak at $2931 \mathrm{~cm}^{-1}$ was attributed to the stretching vibration of the $\mathrm{C}-\mathrm{H}$ bond in glucose, and the weakest peak intensity-reflecting the highest amylose content-was found in WAS followed by AAS, MS, and CS. According to Kizil, Irudayaraj, and Seetharaman [29-50] and Oyeyinka et al., the variation in peak intensity was explained by differences in amylose and amylopectin contents in corn, potato, wheat, and bambara starches. Additionally, significant bond peaks observed at $1566-1656 \mathrm{~cm}^{-1}$ were attributed to stretching vibrations of $\mathrm{C}-\mathrm{O}$ bonds in the amide groups of proteins. The observed peaks at 1566, 1580,1652, and $1656 \mathrm{~cm}^{-1}$ for WAS, CS, AAS, and MS, respectively, reflecting the $\mathrm{O}-\mathrm{H}$ stretching bonds, were also assigned to absorbed water molecules $\left(\mathrm{H}_{2} \mathrm{O}\right)$ in the amorphous (non-crystalline) region [13-50]. The peaks found between 400 and $1162 \mathrm{~cm}^{-1}$ were effectively attributed to $\mathrm{C}-\mathrm{O}$ bond stretching corresponding to vibration strain of the connections of $\mathrm{C}-\mathrm{O}-\mathrm{C}$ and $\mathrm{C}-\mathrm{O}-\mathrm{H}$ in $\beta$-glycosidic bonds [29]. These results are in agreement with those obtained for Quercus ilex L. [13], S. lycocarpum fruits [9], and Chinese ginkgo starches [51].

\subsubsection{Thermogravimetric (TGA) Analysis}

The thermogram (TGA) and its derivative (Dr-TGA) of the studied starches as a function of temperature are plotted in Figure 2. 

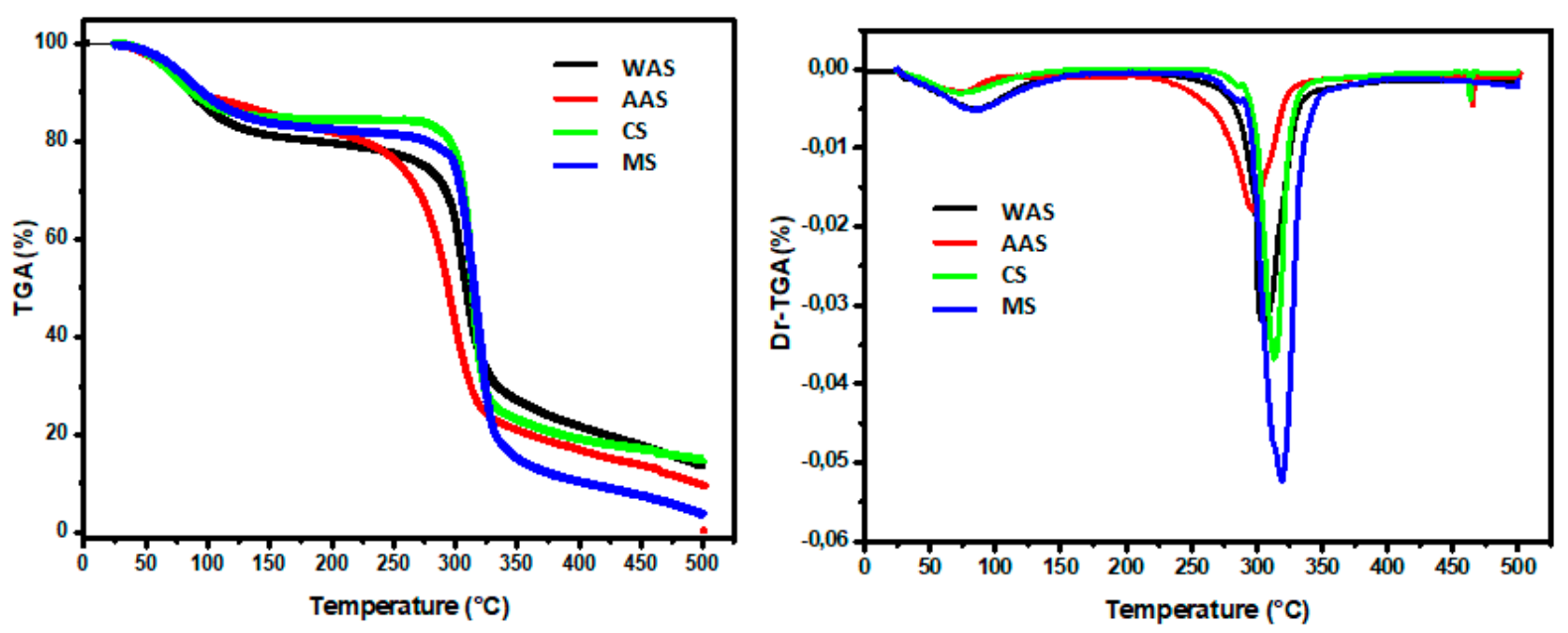

Figure 2. TGA and Dr-TGA curves for different starches. WAS: water acorn starch, AAS: alkaline acorn starch, CS: corn starch, MS: modified starch.

The different starches showed three stages of weight loss in the temperature range between 24.4 and $500{ }^{\circ} \mathrm{C}$. The first stage of weight loss, observed between 24.40 and $141.73{ }^{\circ} \mathrm{C}$, corresponded to the evaporation of water present in all starch samples. The highest weight loss was found in the WAS (17.98\%) sample, followed by MS (16.39\%), CS (15.04\%), and AAS $(10.29 \%)$ samples. After a stabilization stage, an important mass loss was observed between $278.80-332.03{ }^{\circ} \mathrm{C}(60.61 \%), 276-331.37{ }^{\circ} \mathrm{C}(58.22 \%), 237.61-327.61{ }^{\circ} \mathrm{C}(55.35 \%)$, and $254.58-344.28{ }^{\circ} \mathrm{C}(49,53 \%)$ in MS, CS, AAS, and WAS, respectively. As shown, the extracted starch samples (WAS and AAS) exhibited lower mass loss compared to commercial starches (CS and MS). In this second stage, the major mass loss was due to the degradation and depolymerization of starch macromolecules (amylose and amylopectin). Moreover, mass loss values for the extracted acorn starches were lower than those reported by Boukhelkhal et al. [10] on acorns of holm oak (Quercus ilex subsp. ballota (Desf.) Samp.) grown in Algeria: HoS-BC sample (76.07\%), HoSTG sample (65.07\%), HoS-BG (69.76\%), and HoS-YK (67\%). The third stage was observed at temperatures between 327.61 and $500.79^{\circ} \mathrm{C}$ and was the consequence of the carbonization of the inorganic components (fat and protein) and ash formation. Among all starches, the lowest mass loss was observed in the CS sample (10.51\%), followed by MS (14.2\%). These findings indicate the purity of the commercial starches. Results were in accordance with Liu et al. [52], who found in corn starch a reduction in mass of up to $8 \%$ in the temperature range between $150{ }^{\circ} \mathrm{C}$ and $70 \%$ in the temperature range from 250 to $360^{\circ} \mathrm{C}$. Hence, it could be stated that the commercial starches were thermally more stable than the extracted acorn starches.

\subsubsection{Microstructure of Starch Samples}

Obtained results on various starch morphologies are shown in Figure 3. The studied starch granules showed different structures. When observed under SEM, the WAS and AAS granules (Figure 3a,b) were similar in structure and had a spherical and oval shape, with particle sizes ranging from 5 to $12 \mu \mathrm{m}$. These values are generally higher than those reported by Ali et al. [53] and Liu et al. [54] on rice starch $(3.3-8.8 \mu \mathrm{m})$ and chestnut starch $(1-16 \mu \mathrm{m})$, respectively. The surfaces of WAS granules appeared to be more smooth compared to those of AAS granules, which showed the presence of some pores and cracks. However, the CS and MS granules (Figure 3c,d) exhibited asymmetric, irregularly shaped granules with mainly ellipsoid, oval, and prismatic shapes. The particle sizes of CS, ranging from 3.5 to $24 \mu \mathrm{m}$, were similar to those reported by Hernández-Medina et al. [55] (10.6-33 $\mu \mathrm{m})$ for corn and potato starches. The surfaces of the commercial starches appeared to be smooth, with no evidence of any fissures. Among all studied starches, the starch sample extracted by the alkaline method (AAS) showed the most damaged starch granules. This may be due to the use of alkaline solution $(\mathrm{NaOH})$ for starch isolation, which caused damage to the 
amorphous area of the acorn starch, indicating lower resistance of acorn starch to alkali [20]. The variations in starch granule morphology may be due to the extraction and purification methods, environmental conditions, growth stage of the plant, and genotype [1]. In fact, the morphology of starch granules depends on the biochemistry of the chloroplasts or amyloplasts, as well as plant physiology [56]. The microstructural characteristics of acorn starch granules found in this study were similar to those reported by Zhang et al. [20].
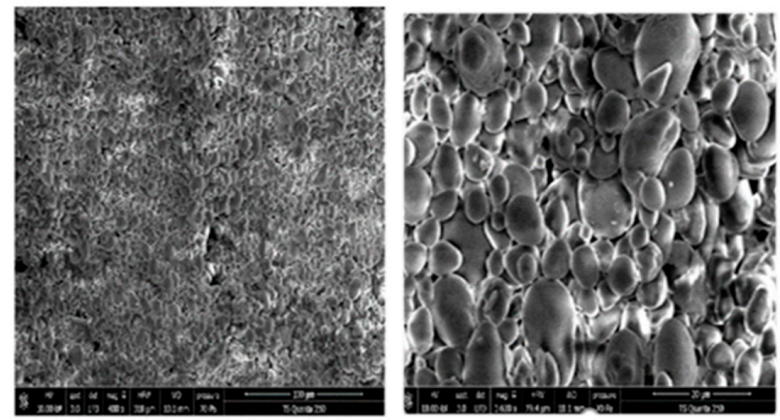

(a)

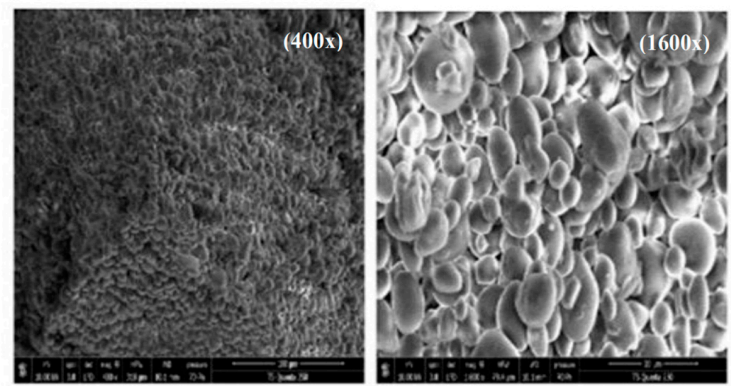

(b)
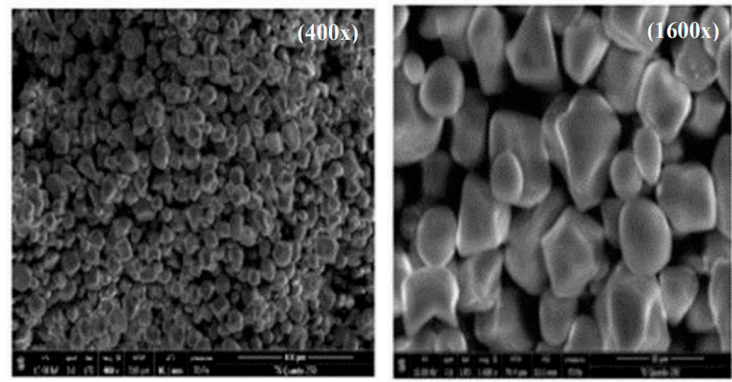

(c)
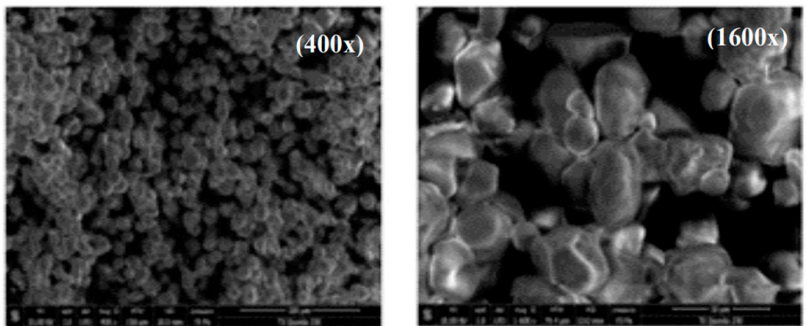

(d)

Figure 3. SEM images of different starches, magnification $400 \times$ and $1600 \times$. (a) WAS: water acorn starch; (b) AAS: alkaline acorn starch; (c) CS: corn starch; (d) MS: modified starch.

\subsection{Characterization of New Custard}

3.2.1. Physicochemical Composition of the Formulated Custard

In order to expand the use of extracted acorn starches at industrial scale, physicochemical properties and syneresis of the control and newly formulated custards were investigated, and the results are presented in Table 5. 
Table 5. Physicochemical properties, composition, and syneresis of acorn starch custards.

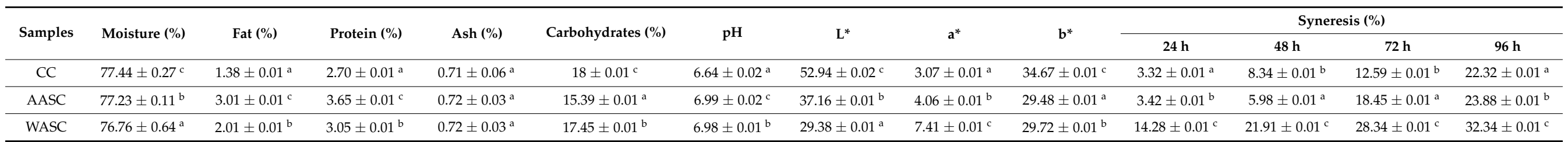

Different letters in the same row indicate significantly different mean \pm standard deviation of triplicates $(p<0.05)$. CC: commercial custard, WASC: water acorn starch custard, AASC: alkaline acorn starch custard. 
Moisture values for prepared custard samples ranged from 76.76 to $77.77 \%$, showing slight changes as a function of the starches used. In fact, polysaccharides are barriers to moisture due to their hygroscopic effect. Carbohydrates were the second major component of custard samples after moisture, with values ranging from 15.39 (AASC) to 18\% (CC). The protein, ash, and fat contents in AASC and WASC samples were substantially higher than those in the control custard (CC). This finding can be explained by the fact that AASC and WASC samples were prepared from crude extracted acorn starches, whereas the CC was made from industrial pure corn powder. The protein and ash contents in formulated custards were lower than those obtained by Salami et al. [57] for corn starch custard, with values of $8.62 \%$ and $4.81 \%$, respectively, for AASC and WASC samples. The pH of custard samples ranged from 6.64 to 6.99, and the highest value was observed in the AASC sample. The custards prepared with acorn starches presented higher $\mathrm{pH}$ values compared to the CC sample. A significant difference was observed in color parameters of the studied custard samples. The CC sample showed the highest $L^{*}$ (52.94) and brightness $b^{*}$ (34.67) values (Figure 4). The redness value $\mathrm{a}^{*}$ ranged from 3.07 (CC) to 7.4 (WASC). These findings are similar to those reported in previous research [57]. Hence, the lower redness and higher brightness might be due to the interaction of other ingredients and the presence of carotenoids in the extracted starches.

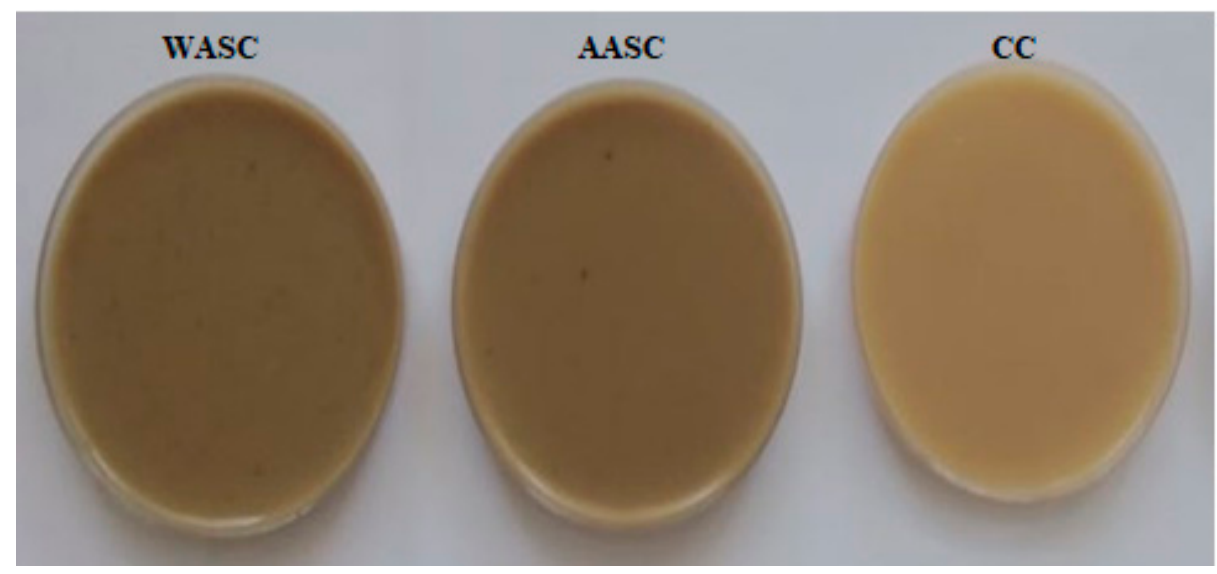

Figure 4. Appearance of different starch custards. CC: commercial custard, WASC: water acorn starch custard, AASC: alkaline acorn starch custard.

\subsubsection{Syneresis of the Formulated Custard}

The syneresis phenomenon is a major appearance-related issue in commercial custard that leads to an increase in whey liquid on the gel surface as a consequence of the reorganization of starch molecules (amylose and amylopectin), and can lower consumer acceptance of refrigerated commercial products [26]. The values for syneresis in different custard samples were in a range of 3.32-32.34\%. As observed in Table 5, syneresis in all custard samples increased under refrigerated $\left(4{ }^{\circ} \mathrm{C}\right)$ conditions with the increase in storage time. The CC sample showed lower syneresis values compared to the WASC and AASC samples throughout the storage period. The highest syneresis value was noted in the WASC prepared with acorn starch extracted by the water method. These results were in agreement with the findings of other studies on custard prepared with some fruits such as: apple powder [58], pineapple peel powder [59], and kiwi fruit marmalade [60]. The higher syneresis in custards prepared with acorn starches could be explained by the thermodynamic incompatibility between extracted starches and milk proteins. According to Sah et al. [59], the syneresis increase was attributed to the contraction of the casein network in the prepared custard samples. 


\subsubsection{Microstructure of the Formulated Custard}

In SEM micrographs (Figure 5), the different starch-based custard preparations showed a homogenous protein matrix where starch was uniformly distributed. In the network of the control custard, some cavities mainly attributed to the break in gel network structure appeared. These results showed that the microstructure of custards depended on starch nature as well as the dispersing phase type. In fact, Velez-Ruiz et al. [61] reported that the preparation of starch-based custard using milk resulted in a denser network when compared to the use of water as dispersing phase.

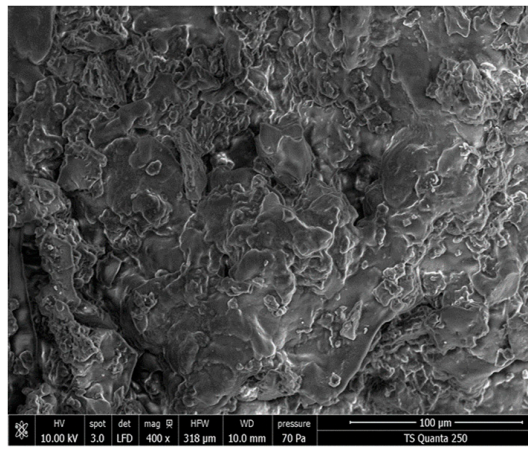

(a)

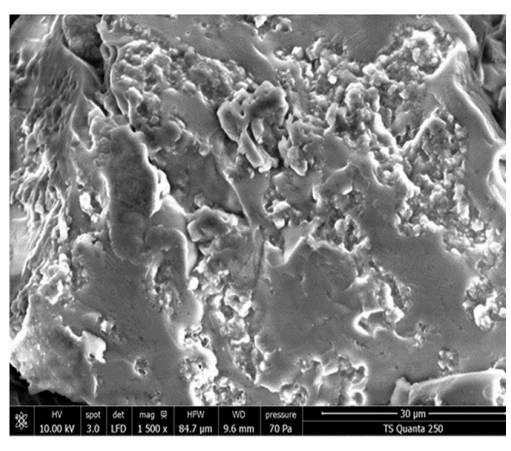

(b)

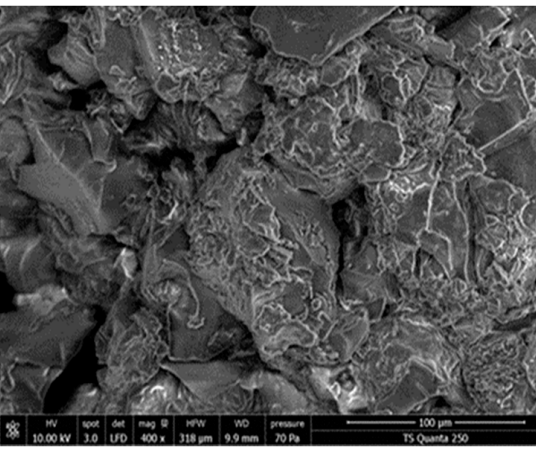

(c)

Figure 5. SEM images of different starch custards: (a) WASC: water acorn starch custard, (b) AASC: alkaline acorn starch custard, (c) CC: commercial custard. Magnification $\times 1600$.

\section{Conclusions}

In this study, starch was extracted from acorn fruits (Quercus suber L.) using hot water soaking and alkaline washing methods. The extracted starches showed interesting physicochemical, functional, and structural properties when compared to commercial starches. The WAS and AAS acorn starches presented a considerable yield (48.32\% and $48.1 \%$ ). It was shown that commercial starches were lighter than the extracted acorn starches. Concerning functional characteristics, starches isolated from acorn fruits exhibited the highest swelling power, solubility, and water absorption, as well as greater enthalpy and gelatinization temperatures compared to commercial starches. Results from surface structure analysis showed that all studied starches had spherical and ovoid granules. However, acorn starches presented a C-type crystalline pattern, while commercial starches exhibited the A-type pattern. Determining the required characteristics of starch is necessary to select the best extraction method according to the application requirements, market trends, availability, structural characteristics, and cost. Moreover, the specific properties of underexploited Quercus suber L. starches encourage their use in innovative food products. Thus, new custards based on isolated acorn starches were prepared. The acorn starch-based custards exhibited interesting nutritional and functional properties and a homogenous protein matrix with uniformly distributed starch granules when compared to commercial custard.

Author Contributions: Conceptualization, Y.Z., M.B.; methodology, B.S. (Bechir Slimi), K.Z., S.N., B.S. (Bouthaina Stiti); writing—original draft preparation, Y.Z., M.B.; writing—review and editing, Y.Z.; supervision, D.S., M.K. All authors have read and agreed to the published version of the manuscript.

Funding: This research received no external funding.

Conflicts of Interest: The authors declare that they have no known competing financial interests or personal relationships that could have appeared to influence the work reported in this paper.

\section{References}

1. Taib, M.; Bouyazza, L. Composition, Physicochemical Properties, and Uses of Acorn Starch. J. Chem. 2021, $2021,9988570$. [CrossRef]

2. Korus, J.; Witczak, M.; Ziobro, R.; Juszczak, L. The influence of acorn flour on rheological properties of gluten free dough and physical characteristics of the bread. Eur. Food Res. Technol. 2015, 240, 1135-1143. [CrossRef] 
3. Jdaidi, N.; Chaabane, A.; Toumi, L.; Hasnaoui, B. Influence of the sanitary state of acorns on the regeneration of Quercus suber in Tunisia. Revue d'Ecologie (Terre Vie) 2018, 73, 71-79.

4. Lin, Y.; Lu, Y.; Song, Z.; Huang, D. Characterizations of the endogenous starch hydrolase inhibitors in acorns of Quercus fabri hance. Food Chem. 2018, 258, 111-117. [CrossRef] [PubMed]

5. Xu, J.; Wang, X.; Yue, J.; Sun, Y.; Zhang, X.; Zhao, Y. Polyphenols from acorn leaves (quercus liaotungensis) protect pancreatic beta cells and their inhibitory activity against $\alpha$-glucosidase and protein tyrosine phosphatase 1B. Molecules 2018, 23, 2167. [CrossRef] [PubMed]

6. Vinha, A.F.; Barreira, J.C.M.; Costa, A.S.; Oliveira, M.B.P.P. A New Age for Quercus spp. Fruits: Review on Nutritional and Phytochemical Composition and Related Biological Activities of Acorns. Compr. Rev. Food Sci. Food Saf. 2016, 15, 947-981. [CrossRef]

7. Chen, X.; Li, X.; Shi, X.; Li, L. Analysis on basic physicochemical properties and antioxidant activities of the starch from acorn Hans J. Food Nutr. Sci. 2019, 8, 195-207. [CrossRef]

8. Foster, J.F. Physical Properties of Amylose and Amylopectin. In Starch Chemistry and Technology, 1st ed.; Whistler, R.L., Paschall, E.F., Eds.; Academic Press: New York, NY, USA, 1965; pp. 349-392.

9. $\quad$ Pascoal, A.M.; Di-Medeiros, M.C.B.; Batista, K.A.; Leles, M.I.G.; Lião, L.M.; Fernandes, K.F. Extraction and chemical characterization of starch from S. lycocarpum fruits. Carbohydr. Polym. 2013, 98, 1304-1310. [CrossRef]

10. Boukhelkhal, M.; Moulai-Mostefa, N. Physicochemical Characterization of Starch Isolated from Soft Acorns of Holm Oak (Quercus Ilex Subsp. Ballota (Desf.) Samp.) Grown in Algeria. J. Food Meas. Charact. 2017, 11, 1995-2005. [CrossRef]

11. Peroni, F.H.G.; Rocha, T.S.; Franco, C.M.L. Some structural and physicochemical characteristics of tuber and root starches. Food Sci. Technol. Int. 2006, 12, 505-513. [CrossRef]

12. Rondán-Sanabria, G.G.; Finardi-Filho, F. Physiscalchemical and functional properties of maca root starch (Lepidium meyenii Walpers). Food Chem. 2009, 114, 492-498. [CrossRef]

13. Zarroug, Y.; Boulares, M.; Mejri, J.; Slimi, B.; Hamdaoui, G.; Djebi, S.; Nasri, H.; Sfayhi, D.; Kharrat, M. Extraction and characterization of Tunisian Quercus ilex starch and its effect on fermented dairy product quality. Int. J. Anal. Chem. 2020, 2020, 8868673. [CrossRef]

14. Özünlü, O.; Ergezer, H.; Gökçe, R. Improving physicochemical, antioxidative and sensory quality of raw chicken meat by using acorn extracts. LWT 2018, 98, 477-484. [CrossRef]

15. Godbillot, L.; Dole, L.; Joly, C.; Roge, B.; Mathlouthi, M. Analysis of water binding in starch plasticized films. Food Chem. 2006, 96, 380-386. [CrossRef]

16. Franklin, M.E.E.; Pushpadass, H.A.; Kumar, B.; Kulkarni, S.; Muthurayappa, M.; Kandasamy, R.; Vellingiri, P. Physicochemical, thermal, pasting and microstructural characterization of commercial Curcuma angustifolia starch. Food Hydrocoll. 2017, 67, 27-36. [CrossRef]

17. Onem, E.; Gulumser, G.; Akay, S.; Yesil-Celiktas, O. Optimization of tannin isolation from acorn and application in leather processing. Ind. Crops Prod. 2014, 53, 16. [CrossRef]

18. Jiang, Q.; Liang, S.; Zeng, Y.; Lin, W.; Ding, F.; Li, Z.; Cao, M.; Li, Y.; Ma, M.; Wu, Z. MicroRNAs and angiogenesis: A new era for the management of colorectal cancer. Int. J. Biol. Macromol. 2019, 125, 1147. [CrossRef]

19. Markom, M.; Hasan, M.; Daud, W.R.W.; Singh, H.; Jahim, J.M. Extraction of hydrolysable tannins from Phyllanthus niruri Linn.: Effects of solvents and extraction methods. Sep. Purif. Technol. 2007, 52, 487. [CrossRef]

20. Zhang, Z.; Saleh, A.S.M.; Wu, H.; Gou, M.; Liu, Y.; Jing, L.; Zhao, K.; Su, C.; Zhang, B.; Li, W. Effect of Starch Isolation Method on Structural and Physicochemical Properties of Acorn Kernel Starch. Food Sci. Technol. 2019, 72, 1900122. [CrossRef]

21. Pérez-Pachecoa, E.; Moo-Huchin, V.M.; Estrada-León, R.J.; Ortiz-Fernández, A.; May Hernández, L.H.; Ríos-Soberanis, C.R.; Betancur-Ancona, D. Isolation and characterization of starch obtained from Brosimum alicastrum Swarts Seeds. Carbohydr. Polym. 2014, 101, 101920-101927. [CrossRef]

22. Singh, J.; Singh, N. Studies on the morphological, thermal and rheological properties of starch separated from some Indian potato cultivars. Food Chem. 2001, 75, 67-77. [CrossRef]

23. AOAC. Official Methods of Analysis of The Association of the Official Analytical Chemists, 18th ed.; AOAC: Arlingto, VA, USA, 2005.

24. Achri, A.; Sukeri, M.; Yusof, M.; Suzeren Jamil, M.; Abdullah, A.; Fairus, S.; Yusoff, M.; Arip, M.N.M.; Mat Lazim, A. Physicochemical characterization of starch extracted from Malaysian wild yam (Dioscorea hispida Dennst.). Emir. J. Food Agric. 2014, 652-658. [CrossRef]

25. Lan, W.; Hihua, Y.; Yun, Z.; Bijun, X.; Zhida, S. Morpho-logical, physicochemical and textural properties of starch separatedfrom Chinese water chestnut. Starch-Starke 2008, 60, 181-191. [CrossRef]

26. Ben Moussa, O.; Rouissi, E.; Boulares, M.; Hassouna, M. Effects of chia seed levels on quality and bio-functional profile of stirred yoghurt. Acta Aliment. 2020, 49, 398-405. [CrossRef]

27. Irinislimane, H.; Belhaneche-Bensemra, N. Extraction and Characterization of Starch from Oak Acorn, Sorghum, and Potato and Adsorption Application for Removal of Maxilon Red GRL from Wastewater. Chem. Eng. Commun. 2017, 204, 897-906. [CrossRef]

28. Correia, P.R.; Leitao, A.E.; Beirao-da-Costa, M.L. Effect of drying temperatures on chemical and morphological properties of acorn flours. Int. J. Food Sci. Technol. 2009, 44, 1729-1736. [CrossRef]

29. Oyeyinka, S.; Singh, S.; Adebola, P.; Gerrano, A.; Amonsou, E. Physicochemical properties of starches with variable amylose contents extracted from bambara groundnut genotypes. Carbohydr. Polym. 2015, 6, 100. [CrossRef] 
30. Shadrack, M.C.; Tilahun, S.W.; Geremew, B.; Mark, L. Characterization of physicochemical properties of starches from improved cassava varieties grown in Zambia. AIMS Agric. Food 2019, 4, 939-966. [CrossRef]

31. Kormin, S.; Kormin, F.; Beg, M.D.H. Physical and mechanical properties of LDPE incorporated with different starch sources. IOP Conf. Ser. Mater. Sci. Eng. 2017, 226, 012157. [CrossRef]

32. Sharlina, M.E.; Yaacob, W.A.; Lazim, A.M.; Fazry, S.; Lim, S.J.; Abdullah, S.; Kumaran, M. Physicochemical properties of starch from Dioscorea pyrifolia tubers. Food Chem. 2017, 220, 225-232. [CrossRef]

33. Usman, M.; Ishfaq, T.; Malik, S.R.; Iqbal, M.; Ishfaq, B. Alkaline Extraction of Starch from Broken Rice of Pakistan. Int. J. Innov. Appl. Stud. 2014, 7, 146-152.

34. Awoyale, W.; Sanni, L.O.; Shittu, T.A.; Adebowale, A.A.; Adegunwa, M.O. Development of an Optimized Cassava Starch-Based Custard Powder. J. Culin. Sci. Technol. 2017, 17, 1-23. [CrossRef]

35. Wang, S.; Li, C.; Copeland, L.; Niu, Q.; Wang, S. Starch Retrogradation: A Comprehensive Review. Compr. Rev. Food Sci. Food Saf. 2015, 14, 568-585. [CrossRef]

36. Ambigaipalan, P.; Hoover, R.; Donner, E.; Liu, Q. Retrogradation Characteristics of Pulse Starches. Food Res Int. 2013, 54, 203-212. [CrossRef]

37. Singh, J.; McCarthy, O.; Singh, H. Starch-A Potential Biomaterial for Biomedical Applications. Carbohydr. Polym. 2006, 64, 569-581. [CrossRef]

38. Correia, P.R.; Maria, L.B. Chestnut and acorn starch properties affected by isolation methods. Starch-Stärke 2010, 62, 421-428. [CrossRef]

39. Correia, P.R.; Nunes, C.; Beirão-da-Costa, M.L. The effect of starch isolation method on physical and functional properties of Portuguese nuts starches. I. Chestnuts (Castanea sativa Mill. var. Martainha and Longal) fruits. Food Hydrocoll. 2012, 27, 10. [CrossRef]

40. Jiang, Q.; Gao, W.; Li, X.; Xia, Y.; Wang, H.; Wu, S.; Huang, L.; Liu, C.; Xiao, P. Characterizations of starches isolated from five different Dioscorea, L. species. Food Hydrocoll. 2012, 29, 35-41. [CrossRef]

41. Cruz, B.R.; Abraao, A.S.; Lemos, A.M.; Correia, P.R.; Nunes, M.C.; Beirão-da-Costa, M.L. The effect of starch isolation method on physical and functional properties of Portuguese nut starches. II. Q. rotundifolia lam. and Q. suber lam. acorns starches. Food Hydrocoll. 2013, 30, 448-455.

42. Kaur, K.; Singh, N.; Singh, H. Studies on the effect of skim milk powder, sprouted wheat flour, and pH on rheological and baking properties of flour. Int. J. Food Prop. 2005, 5, 13-24. [CrossRef]

43. Molavi, H.; Razavi, S.M.A.; Farhoosh, R. Impact of hydrothermal modifications on the physicochemical, morphology, crystallinity, pasting and thermal properties of acorn starch. Food Chem. 2018, 245, 385-393. [CrossRef] [PubMed]

44. Ascheri, J.L.R.; Zamudio, L.H.B.; Carvalho, C.W.P.; Arevalo, A.M.; Fontoura, L.M. Extraction and Characterization of Starch Fractions of Five Phenotypes Pachyrhizus tuberosus (Lam.) Spreng. Food Nutr. Sci. 2014, 5, 1875-1885. [CrossRef]

45. Moorthy, S.N. Physicochemical and Functional Properties of Tropical Tuber 219 Starches. A Review. Starch-Stärke 2002, 54, 559-592. [CrossRef]

46. Ascheri, J.L.R. Characterization of Job's Tears Starch. II. Pasting Characteristics. Alimentaria 1996, 96, 101-104.

47. Teixeira, M.A.V.; Ciacco, C.F.; Tavares, D.Q.; Bonezzi, A.N. Ocorrência e caracterização do amido resistente em amidos de milho e de banana. Ciênc. Tecnol. Aliment. Camp. 1998, 18, 246. [CrossRef]

48. Dome, K.; Podgorbunskikh, E.; Bychkov, A.; Lomovsky, O. Changes in the Crystallinity Degree of Starch Having Different Types of Crystal Structure after Mechanical Pretreatment. Polymers 2020, 12, 641. [CrossRef]

49. Yoo, S.H.; Lee, C.S.; Kim, B.S.; Shin, M. The properties and molecular structures of gusiljatbam starch compared to those of acorn and chestnut starches. Starch-Starke 2012, 64, 339-347. [CrossRef]

50. Kizil, R.; Irudayaraj, J.; Seetharaman, K. Characterization of irradiated starches by uisng FT-Raman and FTIR spectroscopy. J. Agric. Food Chem. 2002, 50, 3912-3918. [CrossRef]

51. Miao, M.; Jiang, H.; Jiang, B.; Cui, S.W.; Jin, Z.; Zhang, T. Structure and functional properties of starches from Chinese ginkgo (Ginkgo biloba L.) nuts. Food Res. Int. 2012, 49, 303-310. [CrossRef]

52. Liu, H.; Yu, L.; Tong, Z.; Chen, L. Retrogradation of waxy cornstarch studied by DSC. Starch-Stärke 2010, 62, 524-529. [CrossRef]

53. Ali, A.; Wani, T.A.; Wani, I.A.; Masoodi, F.A. Comparative study of the physico-chemical properties of rice and corn starches grown in Indian temperate climate. J. Saudi Soc. Agric. Sci. 2016, 15, 75-82. [CrossRef]

54. Liu, C.; Wang, S.; Chang, X.; Wang, S. Structural and functional properties of starches from Chinese chestnuts. Food Hydrocoll. 2015, 43, 568-576. [CrossRef]

55. Hernández-Medina, M.; Torruco-Uco, J.G.; Chel-Guerrero, L.; Betancur-Ancona, D. Caracterización Fisicoquímica de Almidones de Tubérculos Cultivados en Yucatán, México. Cienc. Tecnol. Aliment. 2008, 28, 718-726. [CrossRef]

56. Singh, N.; Singh, J.; Kaur, L.; Sodhi, S.N.; Gill, S.B. Morphological, Thermal and Rheological Properties of Starches from Different Botanical Sources. Food Chem. 2003, 81, 219-231. [CrossRef]

57. Salami, H.O.; Olorunlambe, A.A.; Boluwatife, O.A.; Akinwande, F.F.; Ahmed ElImam, A.M.; Samson, A.O. Physicochemical and sensory properties of corn starch custard soured with tamarind, soursop and lime. Croat. J. Food Technol. Biotechnol. Nutr. 2019, 14, 91-97. [CrossRef] 
58. Senadeera, S.S.; Prasanna, P.H.P.; Jayawardana, N.W.I.A.; Gunasekara, D.C.S.; Senadeera, P.; Chandrasekara, A. Antioxidant, physicochemical, microbiological, and sensory properties of probiotic yoghurt incorporated with various Annona species pulp. Heliyon 2018, 4, 955. [CrossRef]

59. Sah, B.N.P.; Vasiljevic, T.; McKechnie, S.; Donkor, O.N. Physicochemical, textural and rheological properties of probiotic yogurt fortified with fibre-rich pineapple peel powder during refrigerated storage. LWT-Food Sci. Technol. 2016, 65, 978-986. [CrossRef]

60. Tarakci, Z. Influence of kiwi marmalade on the rheology characteristics, color values and sensorial acceptability of fruit yogurt. Kafkas. Univ. Vet. Fak. Derg. 2010, 16, 173-178.

61. Vélez-Ruiz, J.F.; Hernando, I.; González-Tomás, L.; Pérez-Munuera, I.; Quiles, A.; Tárrega, A.; Lluch, M.A.; Costell, E. Rheology and microstructure of custard model systems with cross-linked waxy maize starch. Flavour Frag. J. 2006, 21, 30-36. [CrossRef] 